\title{
NOMADS AND FARMERS IN THE PROCESS OF THE MODERNIZATION OF EGYPT
}

\author{
Hiroshi KATŌ*
}

\section{Preface}

The history of farmers ( fallāhin) was in sharp contrast with that of nomads ('urbān or 'arab) in modern Egypt. While farmers were exalted as the symbol of national identity during the nationalist movement, especially after the 'Orābi Revolution (1881-82), nomads were substantially excluded from "Egyptians" and regarded as a sort of vagabonds without the national consciousness in regards to laws and regulations at the end of the 19th century. This shows what kind of people the Egyptian Government identified as "Egyptians" in those days. In other words, this fact expresses the nature of the process of the formation and the modernization of the Egyptian state and society.

The aim of this small essay is to summarize some characteristics of the modernization process of Egyptian society, by interpreting the above mentioned sharp contrast between the vicissitudes of farmers and nomads in modern Egypt, being the special stress on their participation in the Egyptian National Army. Here, we mean by the Egyptian National Army, the army formed by Muhammad 'Ali, especially by his measure of the draft for military service from farmers in 1822, after having wiped out the former aristocratic military class of Mamlūks and developed afterwards into the National Army after many turns and twists. (1) The reason why we refer to the national army is the well established fact in history that it was one of the key institutions on which the modern state was built, and also which made up the national consciousness among people, besides the modern educational system.

We could discuss the national army from various points of view, but on this occasion, we focus our discussion on its personal components. From this point of view, the national army could be defined as an army composed

* Professor, Hitotsubashi University. 
of the two kinds of military categories, that is, a group of professional officers as commanders, and soldiers drafted from people as combatants, and it is the consciousness of "the National Army" that is shared or is supposed to be shared as principle of unity by both officers and soldiers.

\section{National Army and Farmers}

Now, we will give a glance at the personal components of the Egyptian National Army in the 19th century, from the age of Muhammad 'Ali to the period of English military occupation after the collapse of 'Orābi Revolution. Firstly, as for officers, we can roughly point out the following three tendencies, judging from the analysis on the origins and careers of high officers except royal family's members. The first is the nationalization of their origins. The second is the monopolization of high posts of officers by notable families. And, the third is the emergence of high officers of native origin and especially from middle or low classes of peasants, although they were exceptional. One of these fallăhin officers was the famous Aḥmad 'Orābi, leader of the revolution called after his name.(2) Regarding the theme under study, the third tendency is the most important because it shows that the formation of the National Army produced a powerful effect on the Egyptian society, by functioning a channel introducing the chance of social mobility in Egyptian society and enabling Egyptian peasants to win social promotion.

Secondly, as for soldiers, it has been emphasized until now in the studies on the concerned subject that not only the privileged class of Turkish origin, but also the village notables made efforts to exempt their sons from military service by appealing to various legal measures and often illegal measure of making the peasants under their protection assume their obligations. So, peasants hated the draft as so-called blood tax which deprived them of the labour for cultivation, and many of them sought for the protections of the notables to avoid their recruit for military service.

Undoubtedly we cannot deny these negative aspects of the draft from fallähinn. (3) However, it seems also possible for us to insist its positive aspects counterbalancing negative ones. Regarding these aspects, we have to consider the following three facts. The first is unself-evidence of distinction between village notables and other villagers, because these two groups of people could not defined within the framework of a clear-cut relationship of depend- 
ence, and were related with each other through the kinship and marriage connection on one hand, and the patron-client connection on the other. (4) The second is the importance of the village notables' sons as men of talent for civil and military service to whom the Government dispatched special orders for their recruit, especially at the first stage of the building of the modern Egyptian state. (5) And, the third is the existence of the system of direct petition ('ard or shakwā) to the central authorities against the injustice of local administrators including village notables, which worked as a means to check the abuse of power by village notables, sometimes being combined with severe rivalry among notable families in a village, as can be confirmed in a lot of petitions concerning the draft, possessed in the Egyptian National Archives (Dār al-Wathā'iq al-Qawmìya). (6)

In summary, we can conclude from the above argument that, in spite of its negative aspects mentioned before, the draft was executed more undiscriminatedly than we had expected_-of course we are speaking on a relative level — in rural Egypt. Consequently, as a result of the emergence of fallăhin officers on one hand, and the undiscriminated draft from fallăhin on the other, the rare ideological combination in Arab countries except Egypt between soldiers and nationalism through fallähin was produced. And the person who symbolized this combination in his personality was A hmad 'Orābi, leader of 'Orābi Revolution, the first nationalist movement in modern Egypt in which the nationalist slogan "Egypt for the Egyptians" was advocated for the first time. Since that time, in the process of the rise of Egyptian nationalist movement, "fallạhin" were always exalted as the symbol of national identity regardless of the changes of Egyptian political system, although "fallähin" in reality continued to be the object of exploitation.

\section{National Army and Nomads-Rebellion of 'Omar Maṣrì-}

At any rate, farmers were deeply involved in the National Army, even though they were unwillingly so. As for nomads, the situation was quite contrary. Easily judging from their lifestyle and pattern of action, nomads were always the potential menace to the central power in pre-modern age. They played a marginal, but important role in the Egyptian political history; sometimes when they were in good relationship with the central power, they supported it in battles as subsidiary troops and assured the security of roads 
in desert frontier regions, but sometimes when the central power was weakened, they stood as the toughest enemies in the way of the central power, such as the case of the revolt by shaykh al-'arab Hamām at the time of 'Ali Bik al-Kabir in the second half of the 18th century. (7)

This ambivalent position of nomads to the central power was also reflected in farmers' view on nomads. To farmers, nomads were terrible enemies who suddenly attacked villages, but also they, being independent of administration, were the symbol against the central power, as shown in the circulation among farmers of the traditions of nomadic heroes like the folk epic of Bani Hilāl.(8) In fact, we can observe many cases of farmers' revolts and resistances against the central power under the leadership of nomadic shaykhs, or together with nomadic people.(9)

At any rate, it appears obvious that nomads who respected traditional norms of individualism could be incompatible with the modern state which insisted by nature its absolute control on the people living in its territory. And, it was in the field of the draft for military service that nomads and the state sharply opposed each other.

Under the reigns of Muḥammad 'Ali and 'Abbās, the Egyptian Government promoted the policy of settlement of nomads by giving their shaykhs the lands with the privilege in relation to land tax, and cautiously keeping the custom of exemping nomads from the draft for military service and corvée. (10) However, Sa'id, who was the driving force of the nationalization of the Egyptian Army, broke this traditional custom and ordered the draft for military service from some tribes of nomads. A rebellion which, in our opinion, was a turning point in the history of relationship between the state and nomads was caused directly by this violation of the traditional custom by Sa'id.

The chief of this rebellion was 'Omar Mașrī, shaykh of Jawāzi tribe, being influential in Minyā and Fayyūm Provinces as a settled big landowner.(11) He was called "shaqi" (wretched) and wanted in the official documents during the reign of Sa'id. The state made all the efforts to get informations about him by dispatching spys, and sent the Egyptian regular army when his hiding place was confirmed. The highlight of the struggle between them was the battle in a village named Bilăț in the Province of Dākhla Oasis, in which more than three thousands of Egyptian regular soldiers participated, and a huge amount of blood of rebels and sympathizers was let for execution. 
But, 'Omar Mașri finished to hide himself in the Cyrenaica district of east Libya, after successfully running away in the oasis regions.

We can follow the detailed process of this rebellion, based upon the unpublished documents possessed in the Egyptian National Archives, especially the documents named "mahăfiz ma'ìya saniya turki" (Documents of the Vice-royal Cabinet, Turkish Branch).(12) But here, expecting to take another chance for such a big work in the future, we content ourselves with only introducing an interesting oral tradition about this rebellion, compiled in a book titled Lineages of Arab Tribes (ansāb qabā'il al-'arab), published in Cairo in 1960.(13)

In this oral tradition, 'Omar Mașri, who was a "shaqi" from the view of the state, insists by himself to be, and is treated by others to be, a " $z a^{\prime} \mathrm{i} m$ " (leader) who appealed to the violence only for the resistance against the injustice by the authorities, without doing any harm to common people. And, the reason why 'Omar Mașri rose in revolt against Sa'id, the power of the time, was the opposition about the draft for military service from nomads of 'Omar Mașri's tribe. The outline of this rebellion is as follows.

Sa'id requested 'Omar Mașri to offer soldiers from his tribe. 'Omar Mașri agreed on it, but made the following two proposals as condition for accepting Sa'id's request. The first is that the draft from his tribe should not be compulsory, but voluntary, and the second is that the soldiers drafted from his tribe have the right to continue to wear the traditional costume, especially tarbūsh maghribi (Moroccan turban) with heavy and long tassel, even after their conscription. Sa'id made a concession to 'Omar Mașri by accepting the first proposal. Therefore, at least according to the tradition, the cause of the rebellion which bothered Sa'id during his reign was eventually attributed to the second proposal, that is, whether the soldiers drafted from 'Omar Mașri's tribe wear the military uniform just like other Egyptian regular soldiers, or they continue to wear the traditional costume with turbūsh maghribi.

This rebellion could not be solved until the accession of Ismā'il, the successor of Sa'id, when he proposed the reconciliation between the two by offering 'Omar Mașri the privilege to control the western border territories under his protection. Then, the "shaq" 'Omar Mașri restored his honor by this eventual triumph over the state. 


\section{Conclusion}

This is a very interesting episode. Interesting not because it is a testified historical fact-there is much room for us to study the rebellion of 'Omar Mașri-, but because the contents of this episode, especially the cause and result of the concerned rebellion symbolically expresses the historical circumstances about Egyptian nomads, and the relationship between the state and nomads in mid-19th century.

Firstly, as for the cause of the rebellion, we can easily point out that the opposition between Sa'id and 'Omar Mașri means the opposition between the modern discipline embodied in the uniform of National Army and the traditional custom embodied in the costume with tarbūsh maghribi. And, judging from the fact that the national army functioned the most effective tool to make up the modern national consciousnness among people, this opposition symbolizes the opposition between the type of "modern mentality" and the type of "pre-modern mentality".

Secondly, as for the result of the rebellion, at first glance it shows the defeat or concession of the state to 'Omar Mașri. But, we have to remind the historical fact that the nomadic resistance against the state was hardly observed since the age of Ismā'il, and if we put the rebellion of 'Omar Mașri in this historical context of that time, we can deduce another symbolical meaning from the episode of the result of the concerned rebellion, that is, the end of the opposition between the state and nomads. In fact, under the reign of Ismā'il, the policy of the settlement of nomads was successfully promoted.(14) As a result, shaykhs of nomads came to be organized as local administrators, on one hand, and unsettled nomads were regarded as a sort of marginal vagabonds (tasharrud) without fix residence and job, on the other. ${ }^{(15)}$ In other words, nomadic people gradually became the object with which the Egyptian state was not concerned any longer.

In conclusion, we can deduce from the analysis on the symbolical meaning of the 'Omar Mașri's rebellion in the oral tradition that although 'Omar Mașri himself might receive a concession from the state, nomads as a whole were excluded from the Egyptian national constitution at the end of the 19th century. This is in sharp contrast with the fact that farmers were exalted as the bachbone of the Egyptian national constitution under the British colonial regime. In other terms, the vicissitudes of farmers and 
nomads were the two sides of a coin, or the positive and negative of a film of picture. Of course, the positive was farmers, and the negative was nomads. And, to the quite contrary to the result of the episode of 'Omar Mașri's rebellion in its oral tradition, the farmers of whom the National Army was composed, wearing the military uniform and exalted as a symbol of national identity was the winner to the nomads who hated to be enlisted in the National Army, insisting to wear the traditional costume with tarbussh maghribi and excluded from "Egyptians" in the process of the formation and the modernization of the Egyptian state and society.

* This is the paper read in the Chronological Section: Modern Age, [2] The Modernization of the Arab World of 17th International Congress of Historical Sciences, held in Madrid (Spain) from 27 August to 2 September 1990.

\section{Notes}

(1) On the formation of the Egyptian National Army and the military system in 19th century Egypt, see 'Abd al-Raḥmān Zaki, al-tārīkh al-ḥarbi li-'aṣr muhammad 'ali al-kabir, Cairo, 1950. D. Farhi, "Nizām-i Ceded-Military Reform in Egypt under Mehmed "Ali," Asian and African Studies, Vol. 8 No. 2, 1972. Muḥammad Mạ̣mūd alSurūji, al-jaysh al-mișrĩ fĩ al-qarn al-tāsi' 'ashar, Cairo, 1976.

(2) In 'Abd al-Raḥmān Zaki, a'lām al-jaysh wa al-baḥrìya fi miṣr athnā'a al-qarn al-tāsi" 'ashar, Vol.1 (Cairo, 1948), the 19th century is divided into three periods, namely the period of Muhammad 'Ali, that of Ismā'il, and that of the English occupation of Egypt, and the most eminent officers, whether military or civil, except the royal families in each of these periods are enumerated with their origins and careers; that is, 20 officers for the period of Muhammad 'Ali, 45 for that of Ismā'il, and 44 for that of English occupation.

As for the officers in the period of Muhammad 'Ali, all of them are of European or Turkish origin. As for the officers in the period of Ismā' 11,22 are born abroad and 23 in Egypt, that is 7 in Cairo or Alexandria and 16 in rural districts. It is worth while pointing out that all of 7 high officers born in Cairo or Alexandria are sons of the military or civil notables in the period of Muhammad 'Ali. And, as for the officers in the period of English occupation, 5 are born abroad and 39 in Egypt. Out of 39 officers of Egyptian origin, 32 are described as born in cities or as sons of the military or civil notables, and 7 are born in rural districts, one of whom is the famous fallāh officer, Aḥmad 'Orābi.

(3) The classical work on this theme is H. Rivlin, The Agricultural Policy of Muhammad 'Ali in Egypt, Harvard University Press, 1961. But the following excellent book was recently published. 'Ali Shalabi, al-miṣriyūn wa al-jundiya fi al-qarn al-tāsi" 'ashar, Cairo, 1988.

(4) The detailed discussion on this point can be found in the following case study on the struggle of the village notables. H. KATO, "A Scandal of Village Abū SinētaA case study on the background of the village notables' authority in the mid-nineteenth 
century Egypt-," The Memoirs of the Institute of Oriental Culture (the University of Tokyo), No.99, February 1987 (in Japanese).

(5) The document titled mahâfiz ma'iya saniya turki, mahfaza raqm 10 [II], wathiqa raqm 484, dated 27 Jumādä [II] 1272 A. H. (1856 A. D.) is a list, drawn up for punishment by the Egyptian Government, of the sons of inhabitants of village Büsh in Bani Suaif Province who injured themselves for avoiding their draft. Many of the enumerated in this list are sons of the village notables.

(6) We can find a lot of direct petitions to the Vie-royal Cabinet (al-ma'iya al-saniya) for the exemption of petitioners' sons from military service. For example, in one carton titled maḩăfiz ma'iya saniya turki, mahfaza raqm $2[I I], 22$ petitions, dated Jumādā [II] to Shawwāl 1270 A. H. (1854 A. D.), can be found.

(7) On the revolt by shaykh al-'arab Hamām, see Layla 'Abd al-Lațif, al-ṣa'id $f \bar{i}$ 'ahd shaykh al-'arab hamām, Cairo, 1987. Although there is such an exceptional work as that of Dr. Layla 'Abd al-Lațif, we have only a few works on the problem of Egyptian nomads in modern age except the books written from the nationalistic point of view such as 'Abdullah Muhammad 'Azbāwi, al-badw wa dawr-hum fī althawra al-urābiya, Cairo, 1986. In my opinion, this academic situation in itself shows an ideological reflection of the sharp contrast between the history of farmers and that of nomads.

(8) On the folk epic of Bani Hilāl, see B. Connelly, Arab Folk Epic and Identity, the University of California Press, 1986.

(9) On the peasant revolts, see G. Baer, "Submissiveness and Revolt of the Fellah," in Studies in the Social History of Modern Egypt, The University of Chicago Press, 1969. N. Brown, Peasant Politics in Modern Egypt-The Struggle against the State-, Yale University Press, 1990. 'Ali Barakāt, "intifāḍāt al-fallāḥin fi mișr al-hadith 17691952," 1987. The Japanese translation of the last unpublished article is now in print.

(10) cf. G. Baer, "The Settlement of the Beduins," in Studies in the Social History of Modern Egypt.

(11) 'Alì Barakāt, tatawwur al-milkiya al-zirā'ìya fĩ mișr 1813-1914 wa athar-hu 'alā al-haraka al-siyāsiya, Cairo, 1977, pp. 266-268. 'Ali Shalabi, al-ríf al-mișri fi al-nișf al-thānī min al-qarn al-tāsi' 'ashar 1847-1881, Cairo, 1983, pp. 277-282.

(12) I am now preparing some articles on the rebellion of 'Omar Mașri, based upon unpublished documents possessed in the Egyptian National Archives.

(13) 'Abd al-Salām Hamd al-Hubūni, ansāa qabā'il al-'arab, Cairo, 1966. In the following book, we can also find the description on the rebellion of 'Omar Mașri. Ibrāhìm Ramzi, tārikh al-fayyūm, Fayyūm, 1894, pp. 43-44 .

(14) An Imperial order to Ministry of Finance, dated 28 Jumādā [I] 1280 A. H. (1863 A. D.), is a sort of agreement made between the Egyptian Government and the chiefs of nomads, which is composed of 15 provisions and main whose theme is the settlement of the land left by nomads during their revolts against the State in the reign of Sa'id. cf. mahăfiz abhāth, mahfaza raqm 131, daftar raqm 1910 awāmir 'arabì, s.11. șüra al-amr al-karìm raqm 2.

(15) On tasharrud, see 'Abd al-'Azīz Șabrī, al-tasharrud fi mișr wa 'ilāja ma'a dirāsa muqārana li-l-nuzum al-muttaba'a fí al-duwar al-ūrūbiya, Cairo, 1943. 